\title{
A virada pedagógica da arte e o trânsito de identidades de artista-educador
}

Tatiana Fernández*

Universidade de Brasília

\section{Resumo}

Este artigo foca sobre eventos artísticos da denominada virada pedagógica da arte que Claire Bishop (2012) identifica na arte participante como um movimento que se articula entre a ideia de autonomia e heteronímia da arte. 0 objetivo é observar as tensões entre o sujeito artista e o sujeito educador como espaços de conflito que revelam as relações entre poder e conhecimento herdadas da modernidade. Nessas bases estes artistas instituem novas relações de identidade e apontam sobre coincidências entre arte e educação que contribuem para pensar sobre as mutações que sofrem ambas as áreas no século XXI.

\section{Palavras-chave}

Virada pedagógica da arte; Arte participante; Projeto pedagógico em arte; Partilha do sensível; Ensino como meio artístico.

\section{The pedagogical turn in art and the crossing identities of artist-educator Abstract}

This paper is centred on artistic events from the pedagogical turn in art that Claire Bishop (2012) identifies in participatory art as a movement which is articulated between the idea of autonomy and heteronomy in art. The main goal is to observe the tensions between the artist subject and the educator subject as conflict spaces that reveal power knowledge relations inherited from modernity. On those bases these artists introduce new identity relations and point towards coincidences between art and education that contribute to think on the mutations of both fields for the 21th century.

\section{Key-words}

Pedagogical turn in art; Participatory art; Pedagogical project in art; Distribution of the sensible; Teaching as artistic medium. 
A relação entre arte e educação a partir da modernidade é uma relação de conflito. Um dos indicadores é a persistente dicotomia que se cria na formação da identidade do artista e a identidade do professor de arte nos últimos dois séculos. A estética moderna apontou, principalmente com 0 idealismo alemão, à autonomia da arte e do artista para quem a liberdade era uma regra, enquanto a filosofia da educação pública apontou a uma normatização que procurou homogeneizar a subjetividade e objetivar 0 conhecimento da arte para a sua aplicação na indústria. Mas, entre a diluição dos valores modernos e o surgimento do que os teóricos vieram a chamar de pós-modernidade, estas formas de partilhar o sensível (Rancière, 2009b) foram questionadas e estão sendo reconstruídas. Já na primeira década do século XXI destacam diversos artistas que cruzam as fronteiras entre ambas áreas e rompem ordens instituídas.

Este artigo apresenta na primeira parte uma síntese do trajeto que percorrem diversos artistas entre arte e educação, que é um espaço híbrido e fluído entre o sujeito artista e o sujeito professor (de arte ou de outra coisa). Claire Bishop teoriza a virada pedagógica na arte como um movimento da arte participante e identifica os cruzamentos de fronteiras em que o ensino se torna um meio artístico. Para entender o que essas transformações significam para os artistas contemporâneos, na segunda parte, analisam-se os conflitos, no trânsito entre as identidades de artista e de professor de arte, que surgem na modernidade. Em base à ideia de partilha do sensivel de Jacques Rancière (2005, 2009a, 2009b) observamse como as relações entre poder e conhecimento estão nas bases do conflito. Finalmente, observa-se que a virada pedagógica da arte institui mudanças identitárias que contribuem para pensar as mutações que sofrem a arte e a educação no século XXI.

\section{0 ensino como meio artístico}

Os artistas que trabalham o ensino ou o processo social da educação como seu meio artístico são de uma história recente e se caracterizam por incluir 
o espectador como participante da obra. Essa inclusão do espectador na construção da obra e do seu significado é identificada por Ariano Suassuna (2008) e Bishop (2012) como arte participante ${ }^{1}$. Bishop traça essa linha de protagonismo do participante na arte a partir dos eventos dadaístas da década de 1920 e dos Happenings e ações da década de 1960 onde prevalecem metáforas teatrais². Nesse processo Bishop aponta "a tensão entre a autoria individual e coletiva, o cultivo de uma audiência múltipla e as demandas conflituosas entre agencia e controle" (Bishop, 2012: 78). Trata-se de projetos e eventos artísticos complexos que favorecem o participante e processos de construção de conhecimento relacionados a situações concretas.

Os primeiros artistas a se apropriarem das formas pedagógicas declaradamente foram os artistas do grupo Fluxus na década de 1970. É interessante notar que as caixas Fluxus de George Maciunas (Fig. 1) guardam muita semelhança com os 'presentes' de Friedrich Froebel ${ }^{3}$ (Fig. 2) com o mesmo objetivo de provocar experiências estéticas significativas. Hannah Higgins (2002) lembra que o grupo Fluxus investigava intensamente sobre os processos cognitivos e sobre os artefatos pedagógicos.

\footnotetext{
${ }^{1}$ A arte participante, como a Estética Relacional de Nicolas Bourriaud (2009) se centra na relaçao que se estabelece entre 0 artista, a obra e o público. Na perspectiva da Estética Relacional os artistas se propõem restaurar o vínculo social criando espaços de relacionamento humano enquanto para a arte participante não são espaços de consenso, mas de participação em que o dissenso é possível.

20 teatro da Crueldade de Antonin Artaud e o ballet Triádico da Bauhaus, entre outros.

3 Norman Brosterman (1997) evidencia a influência dos 'presentes' de Froebel (inventor do kindergarten) na geração de artistas das vanguardas modernas, com a exposição Inventando Kindergarten, no Institute for Figurin em Los Angeles, Califórnia, em 2007, como é o caso de Frank Lloyd Wright e Le Corbusier que foram ao kindergarten, ou de Vassily Kandinsky, Paul Klee, Piet Mondrian e Georges Branque se alfabetizaram no espectro da influencia froebeliana. 

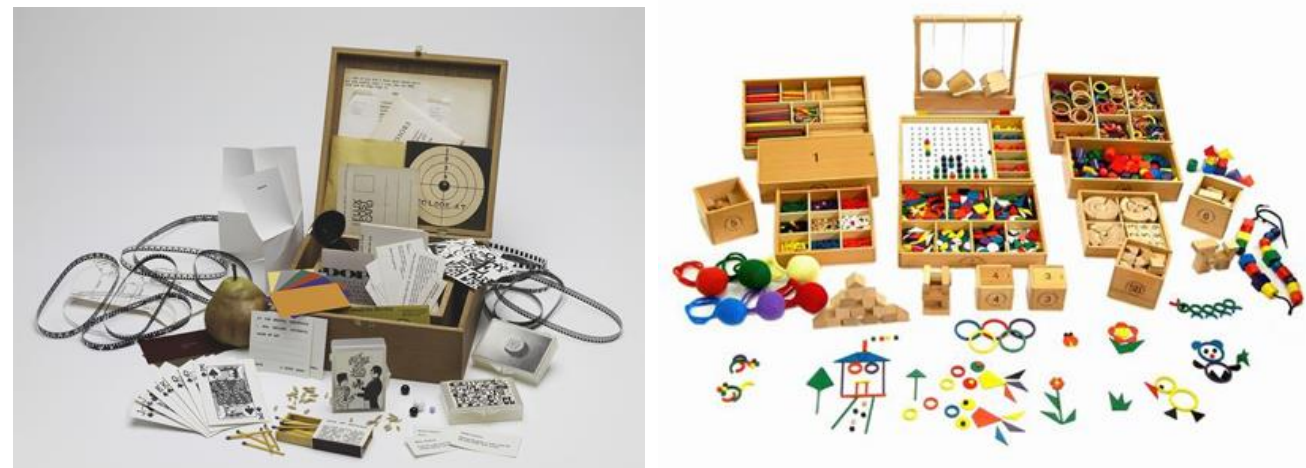

Fig. 1 George Maciunas, Flux Year Box 2, 1960.Fotografia Photograph Service President and Fellows of Harvard College. Fonte: stretcher.org. Fig. 2 Reprodução presentes de Friedrich Froebel Fonte: Picasaweb.

Filliou, que foi um dos artistas Fluxus mais interessados nas relações pedagógicas, realizou diversas obras em que usa formas e estratégias da pedagogia tradicional. Entre essas está o carimbo "Princípio de equivalência: bem feito, mal feito, não feito - Criação Permanente" (Fig. 3) com o qual carimbava e avaliava seus trabalhos. Em 1970 Filliou publicou um multi-livro chamado "Ensinando e Aprendendo como Arte Performática e o leitor, se ele quiser" 4 com entrevistas a Cage, Allan Kaprow, George Brecht, Dieter Roth, Benjamin Patterson e Beuys entre outros, onde deixa espaços para serem preenchidos pelo leitor como coautor, "se ele quiser" (Fig. 4), propondo a descentralização artista no evento artístico e de maneira análoga a descentralização do professor, abrindo espaço para 0 que ainda não está feito. Na página 227 ele descreve o selo o 'Princípio de Equivalência' como um questionamento do ato de criação do universo onde houveram coisas não feitas, além de coisas bem feitas e coisas mal feitas, por este raciocínio ele chega à ideia de que o Universo, o Criador, Deus e a sua Criação, inclusive nós mesmos somos o 'não feito'. Assim fez com muitas das suas obras, apresentando três versões do que ele consideraria bem feito, mal feito e não feito e classificando estas versões com o selo.

${ }^{4}$ N.T.. Teaching and Learning as Performing Art and the reader, if he wishes. 

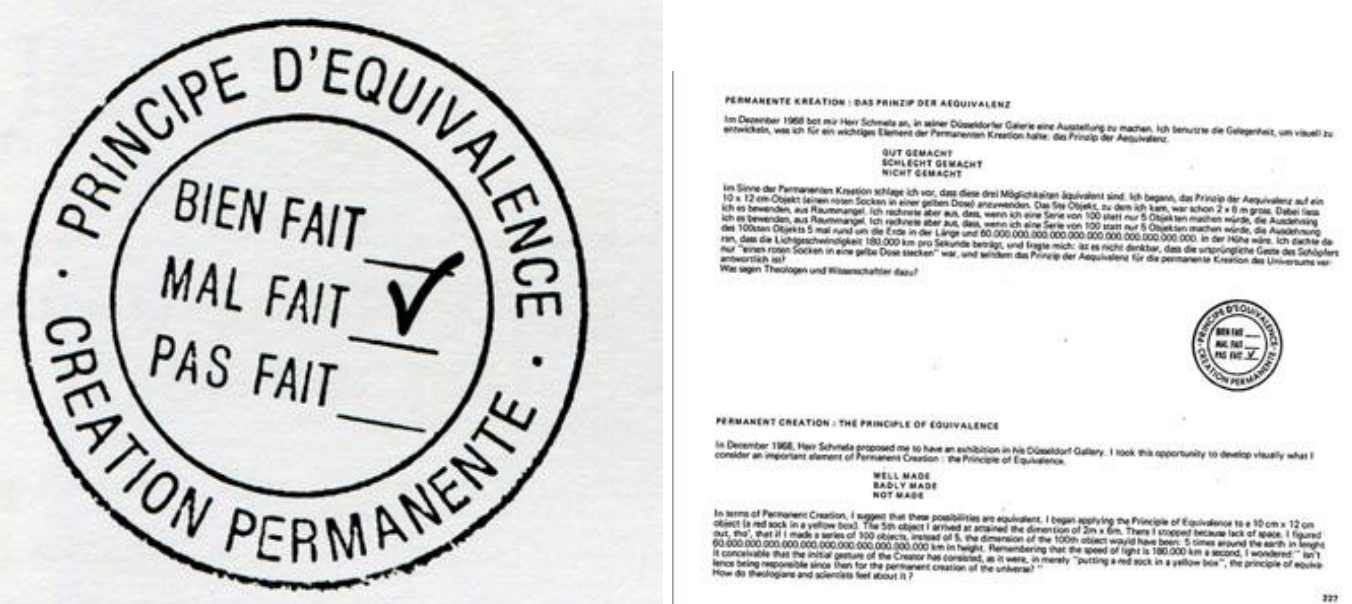

Fig. 3 Robert Filliou. Criação Permanente, selo do Princípio de Equivalência: Bem feito, mal feito, não feito. 1869. Fonte: mediation.centrepompidou.fr. Fig. 4 Robert Filliou, Teaching and Learning as Performing Arts, New York: Kasper Köning, página 227, 1970.

Em 1979 Filliou realizou a versão do "Ensinando e Aprendendo como Arte Performática - Parte II", usando desta vez o vídeo para explorar técnicas de participação do espectador que, segundo ele, podiam ter aplicações no ensino.

Outros artistas do grupo Fluxus também relacionaram sua prática artística às suas aulas como John Cage e lan Baxter, (Baxter\&) no final dos anos 60. Benjamin Patterson apresentou no Fluxus Year Box 2 de 1965, uma carta para ser respondida cuidadosamente com duas escolhas, sim ou não (Fig. 5), colocando em evidência o pensamento binário dos processos educativos. 


\title{
please answer this question carefully.
}

\author{
yes \\ no
}

Fig. 5 Benjamin Patterson. Carta de jogo Fluxus, Fluxus Year Box 2, 1965. Tradução:por favor responda esta pergunta cuidadosamente. sim $\square$ não $\square$.

Mas foi Joseph Beuys quem levou ainda mais longe a apropriação das formas pedagógicas nas suas performances colocando a arte e 0 conhecimento na mesma perspectiva. Ele propôs o 'organismo social como obra de arte' na forma de uma 'conferência permanente', uma espécie de aula constante onde discutia, como se discute numa sala de aula, assuntos políticos com a sociedade. As suas aulas na Academia de Arte de Dusseldorf eram performances que enfatizavam o lugar da aprendizagem como o lugar da experiência da arte. Tanto as fotografias como os vídeos são os registros, os quadros negros onde ele trabalhava suas dissertações pedagógicas são ao mesmo tempo registros e artefatos. Em 1969 ele afirmou numa entrevista:

Ensinar é minha maior obra de arte. 0 resto é desperdício de produto, uma demonstração. Se você quer se expressar você deve apresentar algo tangível. Mas depois de um tempo isto só tem a função de documento histórico. Os objetos não são mais importantes. Eu quero chegar à origem da matéria, ao pensamento que está atrás dele. (Kuoni, 1993: 85)

Nesse sentido a obra pedagógica/artística de Beuys enfatiza o poder da imaginação, da transformação e da intuição que a ciência não alcança por meio do pensamento positivista ou materialista. Ele favorece a ideia de 
cocriação de significado que é a base da estética relacional das seguintes décadas. No entanto é importante a observação que faz Jan Verwoert (2008) sobre as contradições inerentes na obra de Beuys respeito a uma visão 'evolutiva' em que a arte teria um papel transformador em direção a uma melhor condição humana ou a ideia de que o artista e o professor seriam os autores desta transformação. Apesar disso ele favorece o questionamento das relações entre os artefatos de arte e sua localização que antecipa a ênfase contemporânea na especificidade do lugar, ou site especific, que pensa a obra em função específica do contexto e situação em que atua.
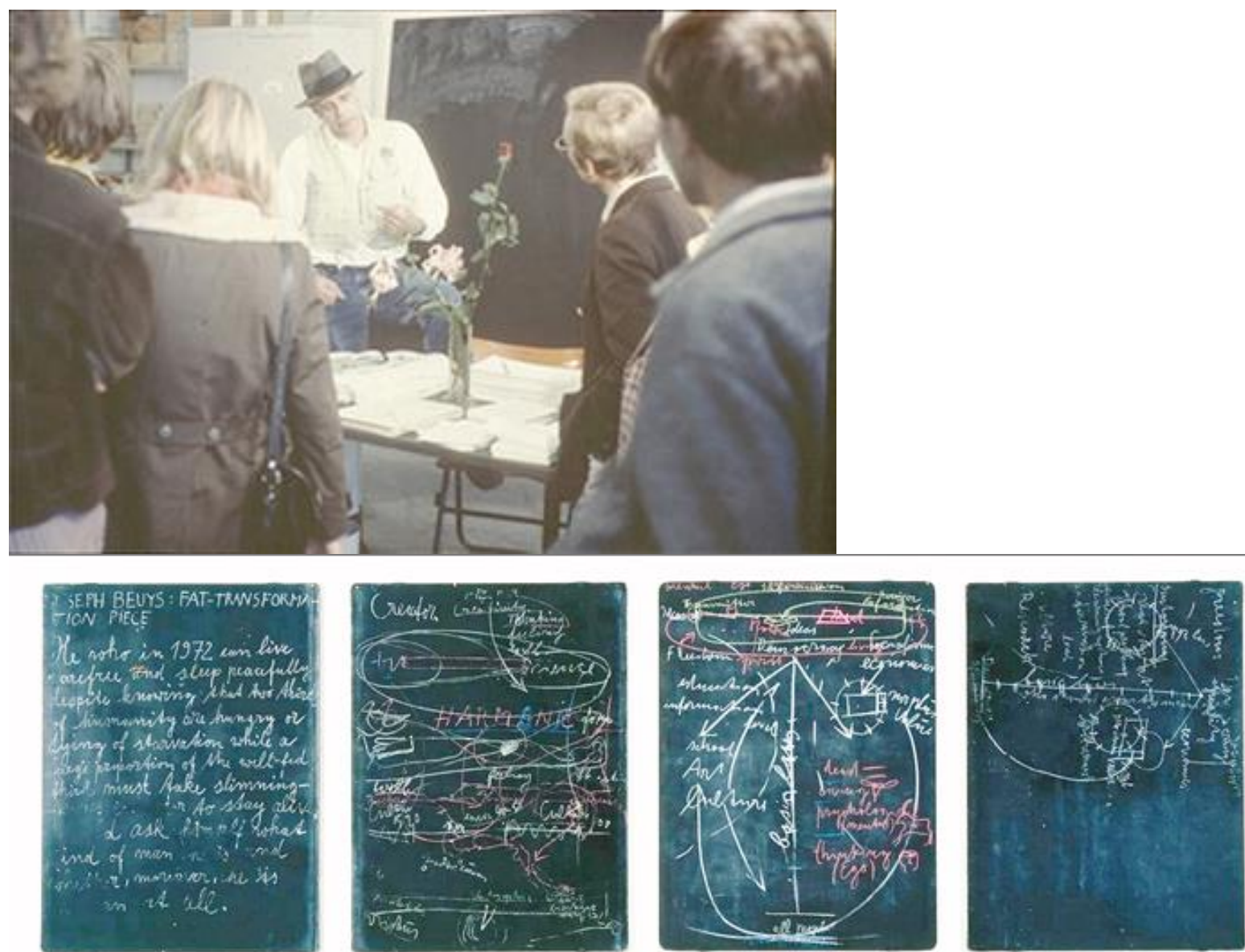

Fig. 6 Joseph Beuys, Escritório para uma Democracia Direta, Tate Londres, 1972. Fonte: Documenta 13 - d13.documenta. Fig. 7 Joseph Beuys, Quatro quadros negros, Tate Londres, 1972. Fonte: tate.org.uk

O interesse pela democratização do conhecimento leva Beuys a fundar em 1974, junto ao escritor Henrich Boll, a Universidade Livre Internacional para 
a Pesquisa Criativa e Interdisciplinar ${ }^{5}$ (em diante FIU) que estabeleceu a preocupação do lugar institucional como intervenção crítica do pensamento (Podesva, 2007). A intenção era despertar a capacidade criativa das pessoas oferecendo um currículo interdisciplinar que integrava economia, sociologia e cultura. Mas antes disso ele já tinha deixado para trás as performances simbólicas e xamânicas por ações pedagógicas como seminários e cátedras sobre estruturas sociais e políticas (Bishop, 2012). Em 1972 ele realizou duas ações-cátedra na Tate e na Whitechapel Gallery em que conversava com o público durante horas. No mesmo ano realizou o "Escritório para uma Democracia Direta"6 (Fig. 6) na Documenta 5 onde se envolveu no debate com o público sobre reforma eleitoral. Os quadros negros que resultaram destas ações - cátedra se acumularam e formaram posteriores instalações da memória do intercambio intelectual (Fig. 7). Em 1977, para a Documenta 6 Beuys realizou "100 dias da Universidade Internacional Livre"7 onde se abriram treze workshops para o público.

Pouca atenção se deu ao trabalho pedagógico de Beuys nos anos 70, mas teve repercussões sobre a arte socialmente engajada que se cria na interseção entre arte, política e educação (Bishop, 2012: 244). Verwoert (2008) é um dos poucos autores que analisam a obra artístico-pedagógica de Beuys e encontra que como professor Beuys se destacava por um engajamento político pedagógico que o levava ao excesso, fazendo dele uma figura subversiva. As cátedras e seminários de Beuys não formam, adverte Verwoert, um metadiscurso sobre sua arte, eles são um meio artístico em si mesmo. No entanto, os críticos o caracterizaram sob uma ideia de mística criativa. Naquele momento, destaca, Bishop (2012), não se entendia o discurso como um evento artístico, o próprio Beuys dividia conceitualmente seu trabalho como escultor e como pedagogo. Os artistas contemporâneos não fazem divisões conceituais entre os diversos

${ }^{5}$ N.T. Free International University for Creativity and Interdisciplinary Research

${ }^{6}$ N.T. Boureau for Direct Democracy

7 N.T. 100 days of the International Free University 
aspectos do seu trabalho, "Hoje podemos reconhecer não só o discurso, mas também o ensino como um meio artístico" aponta Bishop (2012: 245).

Na década de 1990 o interesse pela educação se propaga com os estudos e discussões sobre o currículo das escolas de arte, em especial na Inglaterra. No departamento de arte da Goldsmith University de Londres, que formou os chamados Jovens Artistas Britânicos ${ }^{8}$, os professores e estudantes discutiam o currículo da escola. Este interesse se estendeu de maneira rápida pela Europa (Madoff, 2009). Entre 1998 e 1999 Philippe Parreno, Dominique González-Foerster e Pierre Huyghe, artistas da Estética Relacional de Bourriaud, formaram a Escola Temporária com uma série de workshops em diversas escolas e universidades na Europa. Num deles alugaram um cinema e projetaram um filme narrando potenciais cenários antes de cada parte. Em outro workshop entrevistaram os participantes no meio de um lago congelado e em outro fizeram o workshop na cima de uma montanha. Cada situação era filmada e narrada pelos estudantes e estes registros eram vistos em outros workshops criando uma continuidade (Vidokle, 2006 In Notes for an Art School, 2006).

Em 2001 os dinamarqueses Henriette Heise e Jakob Jakobsen fundaram a Universidade Livre de Copenhagen ${ }^{9}$ (CFU). 0 objetivo era proporcionar um espaço virtual e físico, do tamanho de um apartamento pequeno, para o debate e produção de processos comunitários de conhecimento enfatizando sobre áreas negligenciadas pelas instituições acadêmicas cada vez mais dirigidas ao serviço da indústria estruturada no pensamento corporativista. Durante os seis anos da existência da CFU e baseados na ideia da emancipação da educação dentro da academia e do mundo da arte, artistas e intelectuais investigaram sobre cinco áreas de conhecimento: organização feminista, arte e economia, subjetividade escapista, ativismo de televisão/mídia e história da arte. As investigações na CFU eram coletivas e aproveitaram as potencialidades das redes sociais

\footnotetext{
${ }^{8}$ N. T. Young British Artists

9 N.T. Copenhagen Free University
} 
e do conteúdo gerado pelo usuário como forma de construção compartilhada de conhecimento. Favoreceram também encontros informais em ambientes domésticos onde a cozinha ou a sala com brinquedos de crianças são espaços de investigação e troca de conhecimentos. Os artistas viam esse espaço do pensamento como um espaço público e privado ao mesmo tempo. A CFU reconheceu a natureza ideológica do conhecimento e promoveu uma investigação politizada e socializada que não encontrava espaço nas instituições acadêmicas tradicionais.

Outras iniciativas similares surgiram em outras partes de 2004 em diante, como a Universidade Livre de Los Angeles ${ }^{10}$, a Universidade da Abertura em Londres ${ }^{11}$, a Universidade Livre de Manoa ${ }^{12}$, a Universidade Informal de Grundung ${ }^{13}$, a Universidade Tangente ${ }^{14}$, a Academia Momentânea ${ }^{15}$, a Escola Panamericana da Intranquilidade ${ }^{16}$ de Pablo Helguera (Figuras 8 e 9), entre outras. Algumas já estão fechadas e outras em funcionamento, mas todas se caracterizam pela produção coletiva, pela liberdade de acesso, pela estrutura não hierárquica onde todos são participantes, pelas abordagens experimentais e multidisciplinares, pelo foco em assuntos negligenciados pela academia tradicional, pelo uso de redes de aprendizagem colaborativa, pela natureza subversiva, ideológica e criativa do conhecimento e pela recusa de uma normatização do processo de ensino-aprendizagem (Podesva, 2007).

${ }_{10}$ N.T. Free University of Los Angeles

11 N.T. University of Openess

12 N.T. Manoa Free University

${ }^{13}$ N.T. Informelle Universität in Gründung

${ }^{14}$ N.T. L' Universite Tangente

${ }^{15}$ N.T. Momentary Academy

${ }^{16}$ N.T. School of Panamerican Unrest 


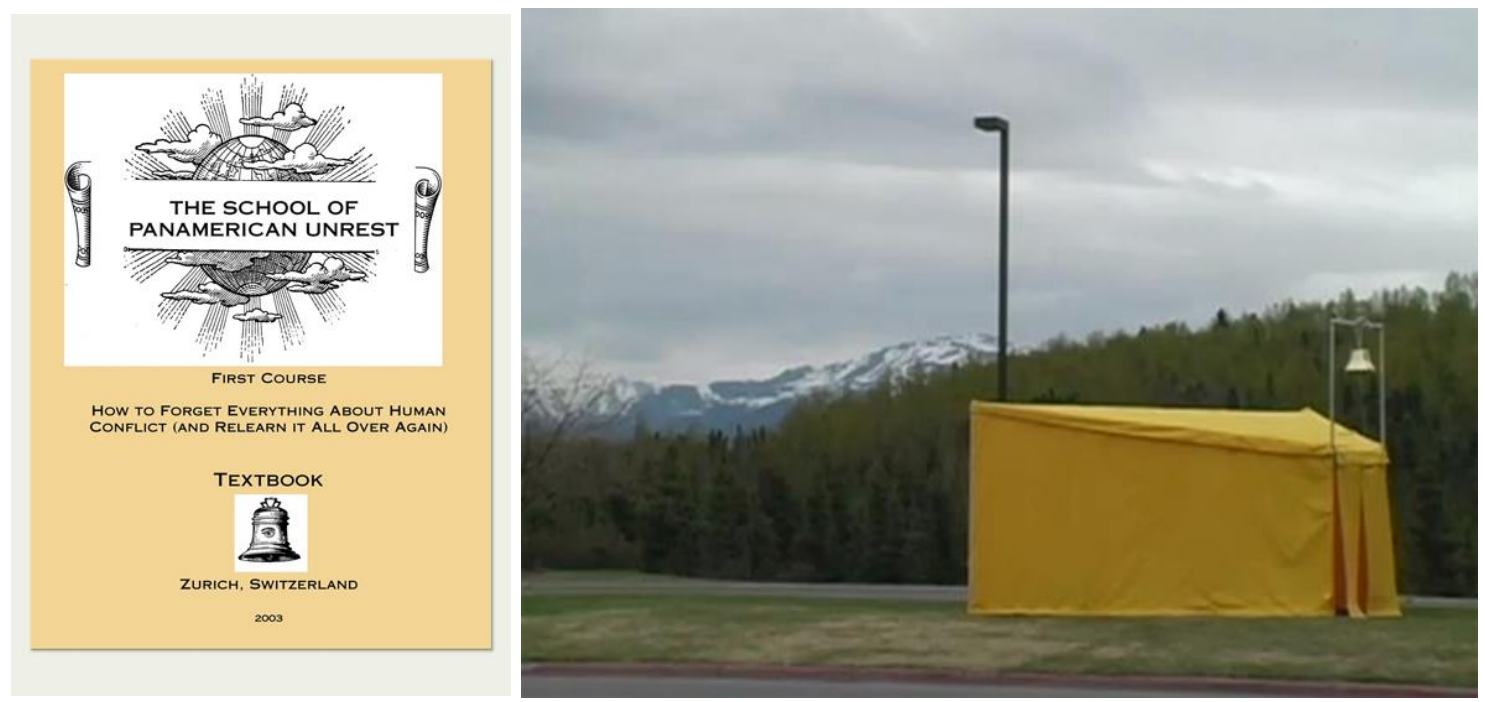

Fig. 8 Pablo Helguera. Escola Panamericana da Intranqualidade.Texto para curso, Suíça, 2003. Fonte: pablohelguera.net; Fig. 9 Pablo Helguera. Escola Panamericana da Intranquilidade, 2003. Fonte: pablohelguera.net

Já os projetos ${ }^{17}$ pedagógicos na linha da arte participante são recentes. Bishop (2012) aponta o surgimento desse interesse em 2000, mas identifica a tendência em 2006 quando o artista-curador Anton Vidokle transforma a Manifesta 6 em Nicósia, no Chipre, cancelada por problemas políticos, em uma escola de arte em Berlim, a Escola Noturna (Figura 10). Hoje é a escola "unitednationsplaza" que dá continuidade à experiência que ele teve com a escola de arte da Manifesta 6. No mesmo ano, Irit Rogoff iniciou o projeto Academie com outros artistas e colaboradores para pensar o museu como um espaço de educação. A ideia de academia era para esses artistas uma metáfora da necessidade de especular, se expandir e refletir além de resultados comprovados, "Nascida da crença de que as instituições que habitamos potencialmente podem ser mais do que são, estas questões indagam como o museu, a universidade, a escola de arte, podem ultrapassar suas funções correntes" (Rogoff, 2008: s/p). Os debates da Academie levaram em conta os debates para a reforma educativa na União Europeia compreendidos no Acordo de Bologna de 199 que promoveram uma educação contável, padronizada, eficiente e subordinada às

\footnotetext{
17 Os projetos na arte contemporânea são um formato que permite procurar e se identificar com o trabalho colaborativo, que tem uma duração, que é situado, que tem um caráter transformador ou construtivo e que envolve uma ou várias comunidades. 
exigências do mercado de capital. Mas esse debate provocou outros sobre acesso e as possibilidades do diálogo (Rogoff; 2008). Nesse contexto numerosos fóruns independentes foram organizados fora das instituições onde se apresentou a educação como uma plataforma de ação, de política e de possibilidade criativa. Ademais, SUMMIT (Non -aligned Initiatives in Education Culture) foi um fórum realizado em Berlim em 2007 que assinalou uma política e promoveu coletivos de ação. Importante notar que, o que une todas estas ações é uma ideia sobre educação: "um lugar para imaginar novas formas de pensar" (Rogoff, 2008. s/p).

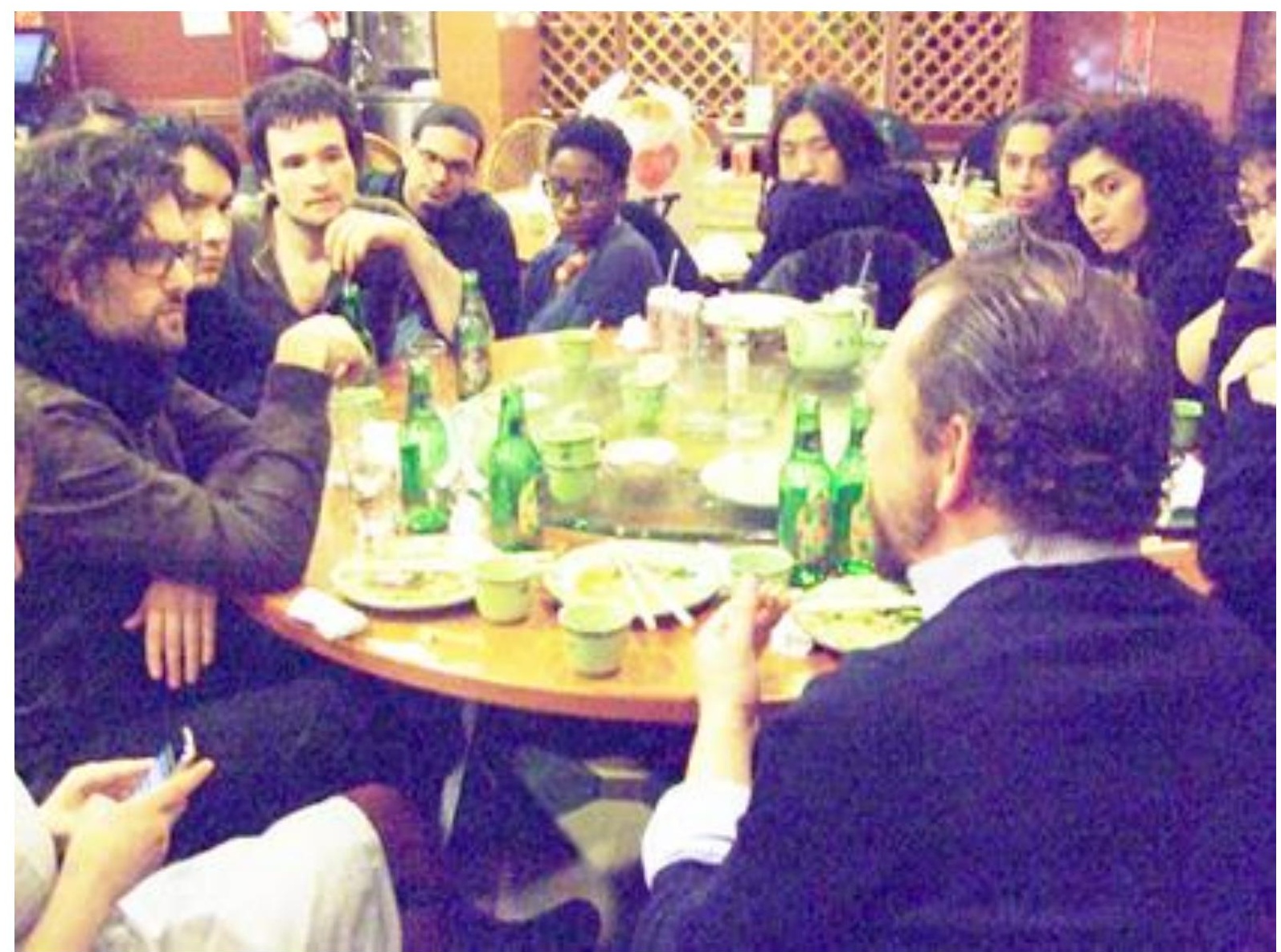

Fig. 10 Escola Noturna de Anton Vidokle. Seminário Público 3. Liam Gillick, Três Textos Curtos sobre a Necessidade de Criar uma Economia da Equivalência. 27-30 março, 2008. Foto Hatuey Ramos Fermin. Fonte: museumashub.org

Desde então, na Europa e nos Estados Unidos, surgiram outras iniciativas institucionais e corporativas que levaram artistas a criar workshops e 
escolas ligadas a museus e galerias. De maneira semelhante, no Brasil ${ }^{18}$ surgem nos últimos anos discussões sobre a formação e o papel dos mediadores e 'oficineiros' nas Bienais, nas grandes galerias, museus e nos espaços culturais institucionais onde os programas educativos ligados à exposição estão em plena experimentação das possibilidades. A virada pedagógica no âmbito da curadoria tornou-se assim uma tendência que cresce e se aprofunda nas políticas da relação entre 0 espectador, 0 artefato e 0 artista.

Em 2007 Luis Camnitzer, artista e curador uruguaio, foi convidado para

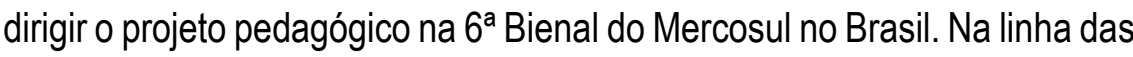
tensões entre arte e educação Camnitzer propôs uma linha de curadoria que, traspassando as fronteiras da bienal tradicional que divide a tarefa curatorial da educativa (na qual a tarefa é educar o público a apreciar os artefatos de arte), se concentrasse na tarefa educativa que pensa nas relações entre o artista e o público (participantes) para incorporar o visitante no processo criativo. Nessa bienal criou-se assim, a figura do curador pedagógico que desenha o Projeto Pedagógico junto com o Projeto Curatorial. A intenção era apontar a arte como uma metodologia para a construção do conhecimento. A ênfase não é "exibir a inteligência do artista, mas estimular a inteligência dos visitantes. Em retorno esta tarefa estimularia nossa própria inteligência como artistas, muito mais do que 0 narcisismo tradicional" pensa Camnitzer (2009: 230).

Nesse sentido a Bienal do Mercosul, ou "Bienal Educativa", propôs preparar os mediadores para pensar junto com o público e não para dar informação detalhada da obra, para enfatizar sobre a especulação antes de repetir informações históricas. De maneira a manter o espaço como um lugar de criação e debate se fizeram estações pedagógicas para os trabalhos de cada artista onde aconteceriam trocas de informação e produção; criaram

\footnotetext{
18 No Brasil esta preocupação pelos programas educativos nos museus surge nos anos 80 ligado às pesquisas de Ana Mae Barbosa no MAC e a implementação do DBAE no Brasil sob a forma de Abordagem Triangular e desde então se desenvolve de maneira constante e ampliada nos programas educativos das exposições. 
espaços de discussão para o público, um centro educacional com biblioteca, estúdios e aulas nos quais professores e estudantes poderiam armar suas aulas dentro do espaço da Bienal. Por outra parte prepararam materiais educativos e investiram na formação de professores como nexos na Bienal. (Camnitzer, 2009).

De toda maneira são muito diversas as aproximações com que os artistas contemporâneos trabalham na virada pedagógica. Rainer Ganahal, Liam Gillik, Jef Gey, Tim Rollins e Patrick Rowe, são artistas que se interessam pelas contiguidades que se geram entre arte e educação. Rollins (Fig. 11) dirige workshops de leitura literária para crianças e adolescentes da escola básica com dificuldades de compreensão leitora e com eles produz elaboradas obras visuais formando coletivos chamados Tim Rollins \& K.O.S. (Kids of Survival) nos Estados Unidos e expondo com eles. Patrick Rowe (Fig. 12) criou um mini estúdio itinerante que oferece workshops para as comunidades por onde passa e onde os participantes que aprendem também ensinam.
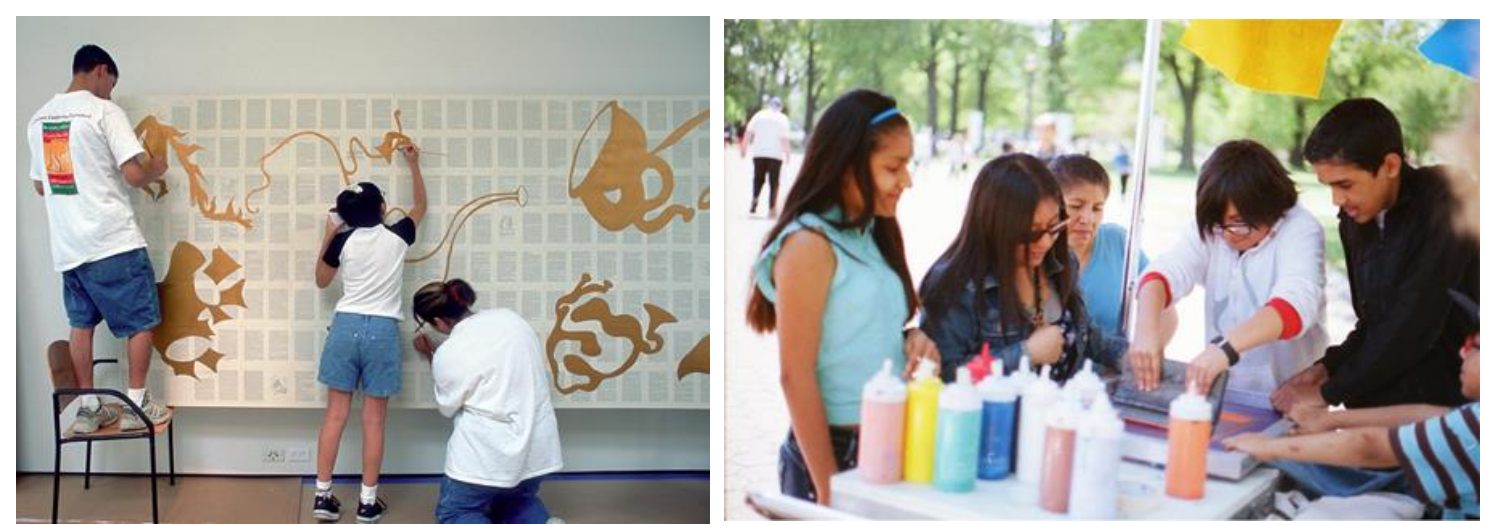

Fig. 11 Tim Rollins + KOS (Kids of Survival) workshop 2007. Fonte: gsa.gov; Fig. 12 Patrick Rowe. Mobile Print Power Collective, 2015. Estúdio móvel para workshops. Fonte:mobileprintpower.com

Outros fizeram intervenções na sua prática pedagógica como 0 artista conceitual John Baldessari (Fig. 13) que nas suas aulas de Post Studio Art na Cal Arts trabalha até hoje com desafios que estabelecem limites arbitrários, ou 'tarefas' para seus estudantes, como as "109 tarefas opcionais" de 1970. 
45. Pun1shment. Write "I w111 not make any more art"

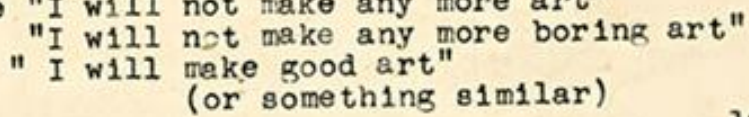

Fig. 13 John Baldessari, Class Assignments, (Optional), 1970. Fonte: wattis.org- Tradução: 45. Castigo. Escrever "Não vou fazer mais arte" / "Não vou fazer mais arte aborrecida"/ "Vou fazer boa arte"l (ou alguma coisa similar)/ 1000 vezes/ na parede

Já a artista Narda Fabiola Alvarado usou estratégias artísticas nas suas aulas do ensino médio na Bolívia em 2003 (embora essas ações não tivessem uma intenção artística), como a proposta em que pediu aos estudantes "espelhos, acessórios para o cabelo e pentes para conversar sobre identidades através de um exercício estético cotidiano: se pentear" (Fig. 14). 

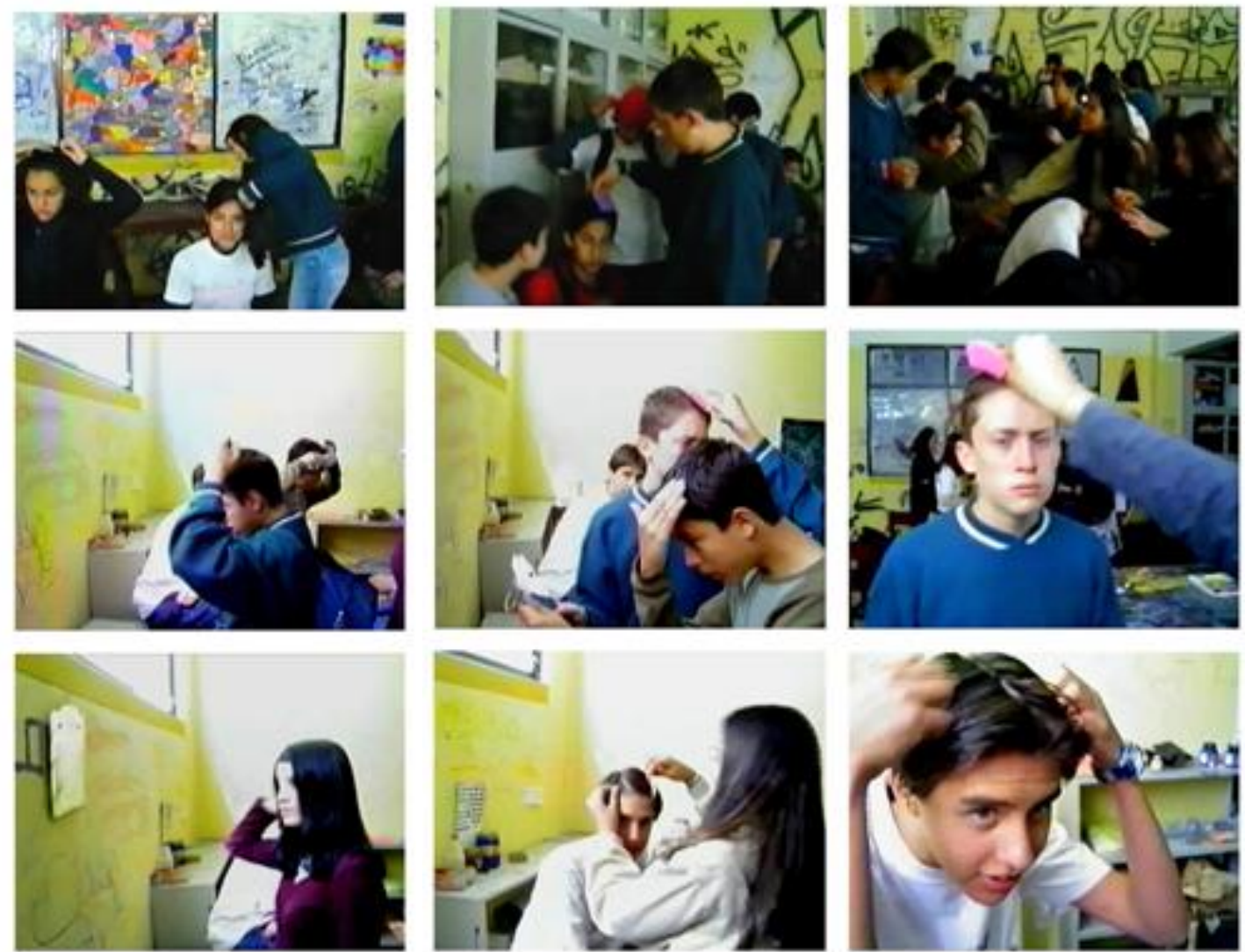

Fig. 14 Narda Fabiola Alvarado. Se penteando. Atividade de penteado com os estudantes numa aula de arte no Colégio Internacional del Sur, La Paz, Bolívia, 2003. Fotografia Narda Fabiola Alvarado.

O artista Paul Chan realizou em 2007, em New Orleans, um ano depois do furacão Katrina, a obra Esperando Godot em New Orleans onde organizou aulas, realizou performances e reuniu fundos para os moradores que não queriam arte, mas ajuda efetiva. Thomas Hirschhorn é um escultor que também realizou vários projetos sociais de larga escala produzindo monumentos junto a comunidades onde se situam as esculturas. Outros como Pawel Althamer fazem esculturas com grupos de adultos que apresentam deficiências mentais. Ele foi comissionado para fazer uma obra comemorativa sobre Albert Einstein em Varsóvia e ao invés de fazê-la desenvolveu em 2006 uma escola de física de seis meses para sete adolescentes delinquentes da cidade, que chamou Einstein Class. $\mathrm{Na}$ mostra Congresso de Desenhistas (Fig. 15) Althamer proporciona ao público espaços em branco e material para intervir a superfície do espaço e das formas. 


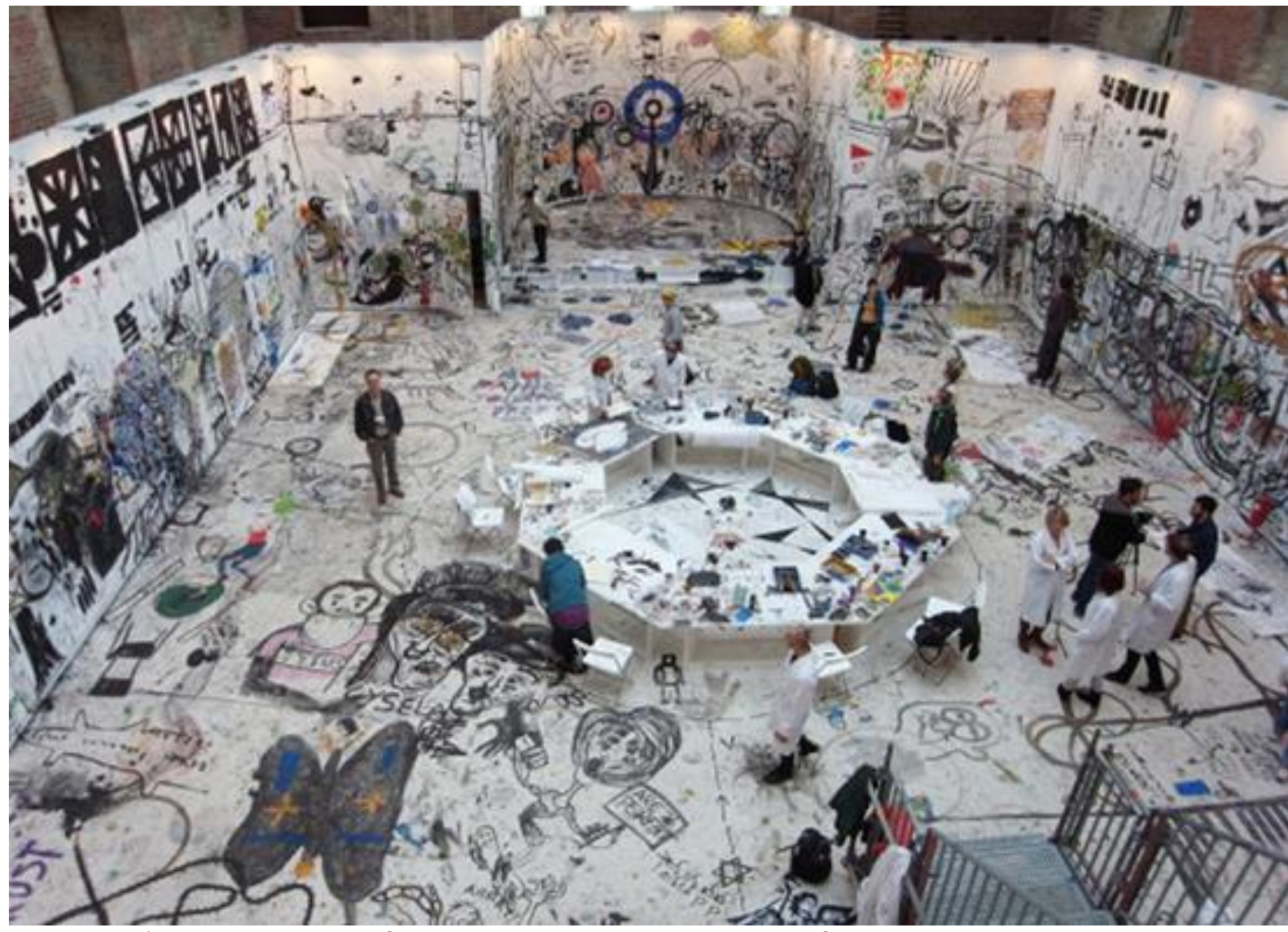

Fig. 15 Pawel Althamer, Congresso dos Desenhistas, exposição Os Vizinhos, New Museum, New York, 2012. Fonte: huffingtonpost.com.

Da mesma forma, nos últimos anos, as galerias aderiram aos projetos educativos de forma ampla. Em 2011 a Hayward Gallery de Londres abriu pelo período de um mês a Wide Open School em que os artistas convidados realizaram aulas abertas como um experimento em educação onde todos podiam participar de diversas maneiras (Bishop, 2012).

Um dos trabalhos mais destacados nessa linha de escolas é o trabalho de Tania Bruguera porque constitui uma das obras mais importantes e longas que investem na virada pedagógica da arte. A escola de arte "Cátedra Arte de Conduta" que Bruguera manteve na Havana entre 2002 e 2009 (Fig. 16) foi pensada como artefato de arte. A artista organizou a escola em períodos anuais com seminários, workshops e reuniões informais onde diversos artistas da comunidade internacional eram convidados junto a críticos e historiadores. Anualmente eram selecionados oito estudantes sobre critérios rígidos, mas uma vez iniciada a escola se abria à participação livre. 
Bruguera considerou esta peça uma intervenção de longo alcance que pretendia criar um espaço de treinamento alternativo ao sistema de estudos de arte na sociedade contemporânea cubana. Para esse projeto Bruguera (Bruguera, s/d) criou três conceitos importantes que são próprios dos espaços de coincidência entre o evento artístico e o evento pedagógico, a saber: Arte de Conduta, Arte Útil e Momento Político Específico.

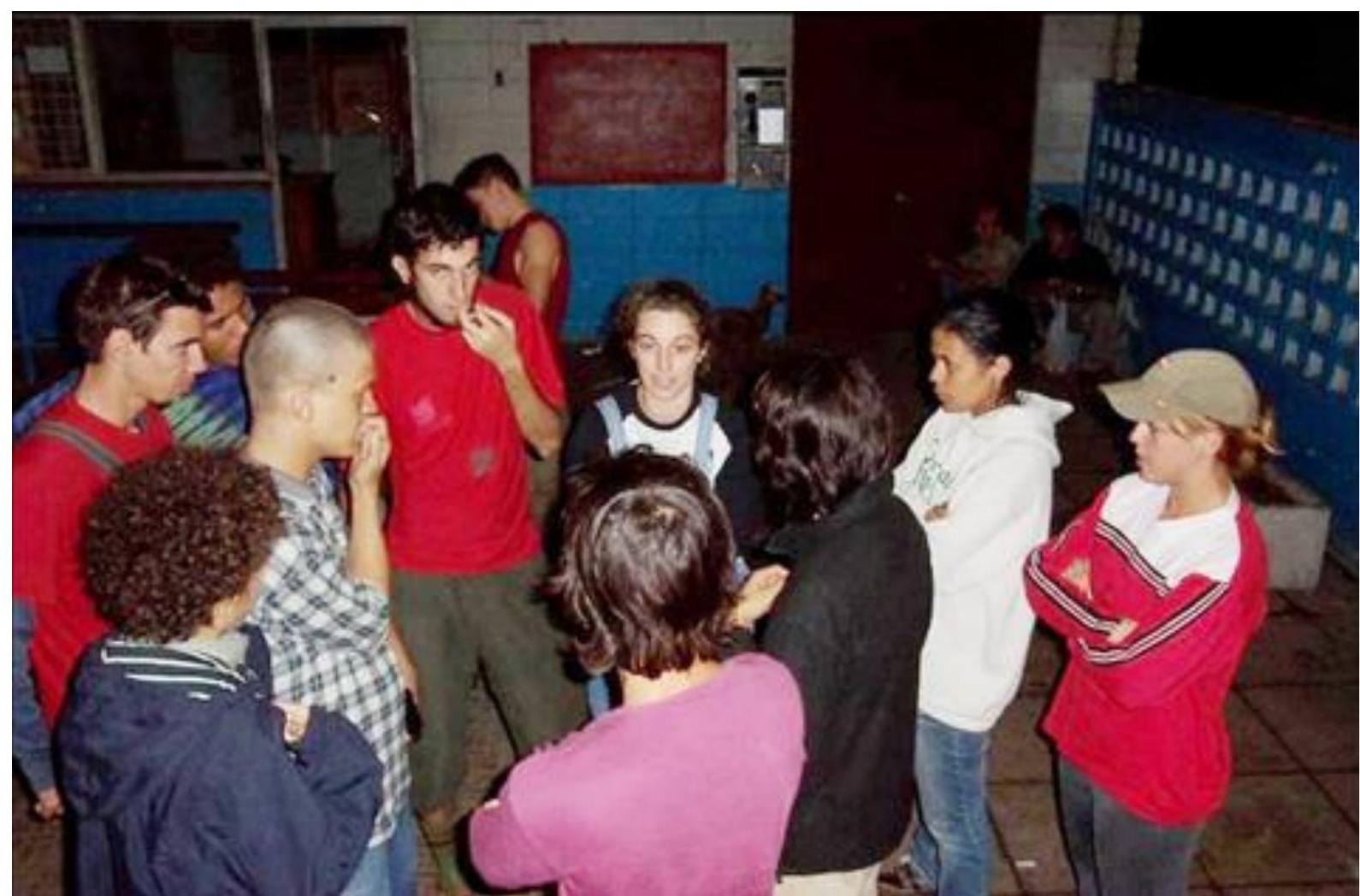

Fig. 16 Aulas. Tania Bruguera, Cátedra Arte de Conduta, Escola de Arte, Cuba, 20022009. Fonte: taniabruguera.com

O conceito de Arte de Conduta aponta as tensões que fazem parte do trabalho performático de Bruguera. Por um lado, remete às instituições cubanas para reabilitar jovens com problemas de conduta social que não podem obedecer às normas do sistema onde Bruguera trabalhou como professora de arte, chamadas "Escola de Conduta" 19. Por outro, refere-se à ideia de performance como conduta social assumindo-o como material de trabalho para realizar arte público e social. Na visão de Bruguera este 
conceito se afasta da preocupação com a forma na arte cujo propósito estético não seja também ético e de uma arte comprometida com a aparência antes que com a função. Arte de Conduta procura os elementos ontológicos da sociedade a partir dos quais pode modificar determinados aspectos dela.

Bruguera sugere que para acercar a arte à vida é necessário pensar em acercar a vida à arte também. $\mathrm{O}$ conceito de Arte Útil é crucial porque pretende transformar alguns aspectos da sociedade por meio de uma arte cujas estratégias possam ter impactos sociais com "soluções para déficits da realidade" (Bruguera, s/d). Este conceito se refere à necessidade de traspassar a brecha que há entre "útil e simbólico", entre "público geral e o público informado" e entre "a linguagem de vanguarda e a linguagem da política urgente, da ciência y outras disciplinas" (Bruguera, s/d).

O conceito de Momento Político Específico parece ser uma reformulação do conceito de site especific (Lippard, 1977; Krauss, 1998; Crimp, 1993) formulado nos anos 70 por escultores e críticos de arte que foca a atenção sobre o espaço existencial antes que sobre o espaço físico em que 0 artefato se constrói. Bruguera apresenta este conceito como um método para conectar o artefato à situação política do momento específico em que se realiza de tal maneira que, passado este momento, a obra perde seu impacto restando apenas o registro como documento do evento. A situação política então define e força da obra que se torna uma estrutura flexível "ao devir dos acontecimentos políticos e suas interpretações" (Bruguera, s/d). Por outra parte aponta a uma duração, a um ritmo que pode ser cambiante.

Já no Brasil a virada pedagógica da arte está ligada, ainda de maneira indireta, à obra de Ligia Clark e Hélio Oiticica que se centram, por influência da fenomenologia merleaupontyana e não do pragmatismo deweyano 20

20 As açoes do Fluxus encontram suas bases na ideia de experiência estética de John Dewey em "Arte como Experiência" publicado por primeira vez em 1934 (2005) e Dewey é reconhecido como filósofo pragmático (HIGGINS, 2002). 
como foi para o grupo Fluxus, sobre a experiência da arte e sua relação com as necessidades da vida onde os participantes são ao mesmo tempo o meio e o fim. Nesse sentido Agusto Boal é, entre os artistas brasileiros, quem mais explorou os espaços entre a educação e as artes cênicas na interpretação da Pedagogia do Oprimido de Freire (1987) por meio do Teatro do Oprimido. Em todos eles a ênfase da participação na arte como uma experiência liberadora estava ligada a um maior interesse pela sensualidade que a filosofia fenomenológica favorecia, eles "invitam 0 público a sentir" (Bishop, 2012: 106).

De maneira similar, alguns artistas conceitualistas argentinos exploraram entre os anos 70 e 80 uma arte social e politicamente engajada no período mais repressivo das ditaduras latino americanas com estratégias que procuravam a emancipação do pensamento da maneira similar à Pedagoga do Oprimido de Freire. Mas, na Argentina, em que houve uma maior influencia da semiótica e das teorias comunicativas europeias no pensamento dos artistas, era mais importante analisar do que sentir. Dessa forma realizaram-se obras que, à diferença dos artistas brasileiros, procuravam performances e situações menos visuais e mais agressivas que sujeitavam os participantes a formas de coerção como as ações de Graciela Carnevale ${ }^{21}$ ou as intervenções no tecido social como Tucumán Arde que foi realizado de maneira colaborativa por um grupo de interdisciplinar argentino em 1968 para visibilizar a opressão dos trabalhadores no período da ditadura. León Ferrari fez parte do grupo e define o sentido político e pedagógico da arte, que "não seria mais beleza ou novidade, mas eficácia e perturbação [...] um ato terrorista em um país que luta pela sua liberdade" (Longoni, 2000, apud Bishop, 2012: 127). Isso indica não uma renuncia estética, mas um programa ético que é estético ao mesmo tempo porque visualiza o conflito e se envolve no centro dele.

${ }^{21}$ Em 1968, como parte de uma série de ações do chamado Ciclo de Arte Experimental em Rosario, na Argentina a artista tomou prisioneiras as pessoas que foram assistir sua obra sem saberem que seriam trancados numa sala vazia cuja parede de vidro dava à rua. A artista não pretendia liberá-los até que eles conseguissem fazer isso por si mesmos. Foi uma pessoa da rua que quebrou o vidro por onde os participantes puderam se liberar. 
Os artistas conceitualistas latino americanos, à diferença dos artistas norte americanos e canadenses, não estavam interessados na crítica ao sistema de consumo e do espetáculo na construção dos espaços relacionais. E, à diferença da Situacionista Internacional, não recusava um programa artístico. Os eventos artísticos na América Latina se destacam pelas tensões entre arte e vida.

Nesse cenário o discurso da autonomia da arte abre espaço para questionar as contradições da sociedade e o discurso da arte socialmente engajada abre espaço às provocações para uma mudança social. Para Bishop (2012), ambas criam tensões que alcançam pontos culminantes e recorrentes nos períodos de maior instabilidade política e social: nos anos do surgimento do Fascismo italiano, nos anos que seguiram à Revolução Russa e nos levantamentos sociais de 1968. Da mesma forma podemos identificar tensões na década pós-9/11 em que o mundo vive uma guerra global sem fim. A história da identidade do participante é também remanejada de acordo a estas mudanças políticas: "a multidão (1910), as massas (1920), o povo (1960-1970), os excluídos (1980) a comunidade (1990) e os voluntários" (Bishop, 2012: 277).

O conceito de participação ou colaboração não garante nada, também foram conceitos intensamente usados pelas ditaduras como foi pelo fascismo e hoje é usado de maneira indiscriminada e paradoxal pelo mercado de capital. A diversidade de manifestações da arte participante obedece justamente a um Momento Político Específico que informa os propósitos e os meios em que a arte se manifesta. Os artistas que trabalham com projetos pedagógicos fazem parte de um movimento que procura responder a um momento de extrema crise política e social, mas também procuram lidar com uma nova proximidade entre espetáculo e participação e ampliar a arte ao espaço da experiência estética.

Nesse cenário é necessário indagar sobre uma questão fundamental na virada pedagógica que foca sobre os participantes: qual é o papel do artista 
nessa relação? O que significa essa virada no trânsito de identidade entre sujeito artista e sujeito educador?

\section{As identidades em trânsito}

No final do século XIX, com os valores da liberdade, individualidade e independência promovidas pelo lluminismo e mais tarde pelo idealismo alemão e as mudanças provocadas pela revolução industrial o valor dos métodos de aprendizagem acadêmicos que datavam do século XVII caducaram. No lugar das academias de belas artes os artistas passaram a estudar em ateliers dirigidos por mestres artistas reconhecidos (Efland, 1990). As universidades eram para as cientistas e as escolas de artes e ofícios para os artesãos. Essas últimas cumpriam a função social que as academias de belas artes não assumiam formando artesãos/designers preparados para cobrir as necessidades do conhecimento estético aplicado à indústria que era diretamente usado na vida cotidiana.

Os (as) professores(as) para as escolas de artes e ofícios e para as escolas públicas estudavam em escolas normais de arte que apareceram primeiro na Inglaterra e nos Estados Unidos 22 . Arthur Efland (1990) argumenta que essa foi uma mudança radical no mundo das ideias: por primeira vez se formaram professores de arte que não eram artistas. As críticas que se faziam tinham duas razões opostas, por uma parte argumentava-se que era desenho industrial ${ }^{23}$ e não arte o que se ensinava e por outra se criticava 0 custo alto de uma aprendizagem que, por não ser uma ciência, carecia de utilidade ou benefício. As escolas de artes e ofícios e as escolas vocacionais solucionaram a formação de mão de obra industrial a um custo menor. Houve desta maneira um distanciamento entre as artes visuais e 0 trabalho ligado à economia produtiva nos países do Norte da Europa e da América.

22 South Keningston na Inglaterra e Massachusetts Normal Art School nos Estados Unidos.

23 Walter Smith deu o nome de desenho industrial ao tipo de desenho que se ensinava na Normal Art School na década de 1870 nos Estados Unidos. 
Nesse contexto o papel do artista se articulava no começo do século XX, entre o sistema da arte, a academia e as necessidades educacionais. Isso significou uma separação abrupta entre o que era ensinado da arte nas escolas públicas, as escolas privadas, as academias, as universidades e as escolas de artes e ofícios, constituindo assim uma realidade fragmentada sobre o papel e a importância da arte nas sociedades ocidentais. Até as primeiras décadas do século XX ainda se acreditava que ser artista era um dom com o qual se nascia, portanto não podia se formar, mas se encontrar artistas. Em termos de investigação isto significava, segundo Graeme Sullivan (2010), que os estudantes de arte indagavam sobre sua identidade artística antes que sobre as questões que interessam ao mundo científico ou ao campo social.

A Bauhaus (1919-1930) foi a primeira instituição em investigar sobre a contiguidade entre criação subjetiva e construção objetiva de uma estética moderna e o fizeram num contexto pedagógico. Walter Gropius acreditava na importância da arte na educação e na formação da visualidade cultural alemã (mas também europeia e internacional) no cenário moderno. Entre os objetivos essenciais do programa indicava-se a "alocação e dedicação total dos artistas no sistema educacional escolar" (Argan, 1993: 340). Wassily Kandinsky e Paul Klee entre outros pesquisaram uma didática da arte diferente daquela que era praticada nas velhas academias, mas artistas como Piet Mondrian não abraçaram a ideia da contiguidade entre arte e indústria porque isto significava renunciar ao prestígio do gênio (Argan, 1993).

O prestígio do gênio estava ligado à ideia da arte pura ou ideia da autonomia da arte relacionada à noção kantiana do desinteresse que libera a arte de toda ideologia, de toda norma, das exigências do público e das funções utilitárias e pedagógicas. Mas, o que Suassuna (2008) denomina de 'arte gratuita', não é a única linha moderna. Ele nos lembra que frente a ela a arte participante sempre tem uma tese a defender com uma função social definida. A heteronímia da arte é assim a sua relação de dependência 
e interação ou utilidade com outros conhecimentos ou aspectos da vida. Nos extremos destas duas linhas, pensa Suassuna, existe respectivamente o risco da desumanização e da propaganda.

Essas dicotomias entre a autonomia e a heteronímia da arte, que para alguns artistas e teóricos modernos são irreconciliáveis, são parte de um conjunto de suposições que circundam a arte na era moderna. John Dewey (2005) chama de 'ideia esotérica da arte' a essa visão que parte da suposição de que o valor que a arte possui é tão único que não tem conexão com os conteúdos de outros modos de experiência que não são estéticas. Thomas Mitchell chama isto de 'falácia naturalista' (Mitchell, 2003 apud Aguirre, 2011) porque se parte da suposição de que a arte não faz parte do regime culturalmente constituído, sendo assim a arte seria parte da natureza e não algo que se debate no terreno das contingências sociais, políticas e econômicas que formam a cultura.

Essa é uma posição essencialista assumida muitos artistas modernos, mas também por críticos e teóricos como Clement Greenberg, que distingue a arte como repositório dos valores civilizados quando esta se concentra na especificidade do seu médium. Assim, no sistema social moderno europeu se reconhece 0 artista como repositórios dos valores ligados às classes dominantes por uma "corda umbilical de ouro" (1996, In Ferreira; Contrim, 2001: 31) como pensa Greenberg. Isso significa que a pureza da arte e do seu meio procura preservar, sob um sistema de significados, a pureza da civilização branca e ocidental dos valores considerados defasados, mundanos e primitivos.

Essas ideias permitem observar que a dificuldade dos essencialistas não é compreender a arte como um produto social que tem um valor de mercado em determinado sistema econômico, pois não se incomoda em produzir commodities para esse sistema. O que the incomoda é a ideia de 'reduzir' a sua prática a uma arte inferior (porque parte da ideia de que há artes superiores e inferiores) e o seu status social a uma ruptura com o sistema 
de poder. E a grande dificuldade da identidade do sujeito artista como sujeito docente é análoga. É, portanto, uma questão ideológica ligada, não tanto à usabilidade da arte, mas à divisão das classes sociais e às relações de poder e dominação.

Mas, isso tem mudado com as identidades mais líquidas (Bauman, 2006). A virada pedagógica da arte é uma forma de pensar a arte e a educação como espaços de hibridação e fluxo, espaços de contaminação e rompimento ou espaços de tensão entre fronteiras. Para entender essa forma de pensar Bishop aponta a ideia de estética política de Rancière (2005, 2009a, 2009b) que se expressa através da noção de 'partilha do sensível'. Ele reconstrói a noção do estético no sentido de aesthesis, ou modo sensível e defende a ideia de autonomia na arte, mas Bishop (2012) observa que ele considera a autonomia da nossa experiência em relação à arte antes que a autonomia da arte como foi para a estética moderna. Não se trata então de ser livre das exigências do público, da função utilitária ou didática da arte, mas ser livre para questionar, imaginar novas cartografias artísticas e participar na mudança e redistribuição do sensível. A estética e a política coincidem na sua preocupação pelo compartilhamento de ideias, habilidades e experiências na vida, portanto um julgamento estético é sempre um julgamento político, pensa Rancière.

Hoje, as entidades que financiam atividade artística em muitas partes do mundo, exigem cada vez mais que os projetos artísticos incluam um retorno social. Essa tendência vem sendo chamada de 'virada social da arte'. Para Rancière essas formas denotam o "colapso do dissenso na arte e na política em novas formas de ordem consensual" (2004, apud Bishop, 2012: 28). Ele afirma que assim como na política da guerra o discurso dominante tende a distinguir uma 'maldade infinita' de uma 'justiça infinita' assim na arte 0 discurso dominante tende a distinguir uma arte que procura a restauração do vínculo social (Bourriaud, 2009), de uma arte que apresenta a visão da catástrofe. A arte para Rancière deve procurar a tensão que a faz existir em si mesma e além de si mesma: 
A estética para Rancière assinala uma habilidade para pensar a contradição: a contradição produtiva da relação da arte com as mudanças sociais, que se caracteriza pela paradoxal crença na autonomia da arte e em seu inextricável vínculo com a promessa de um mundo melhor a vir. Em quanto esta antinomia é a aparente em muitas práticas vanguardistas no último século, parece particularmente pertinente analisar a arte participante e as narrativas legitimadoras que atrai. Em resumo, o estético não necessita ser sacrificado no altar da mudança social, porque ela sempre tem a promessa da melhoria. (Bishop, 2012: 29)

Os artistas que trabalham com projetos pedagógicos incursionam em situações que procuram essas tensões e contradições. Apesar de ser ainda uma tendência marginal no mundo da arte atualmente existe um maior interesse dos artistas pela relação entre arte e educação ou arte e academia. Se antigamente a academia era associada a uma instituição já estéril hoje, como vimos, se converte em uma aliada num contexto em que o espaço público se torna cada vez mais privado (Bishop, 2012) como tendência global. Ademais, Rogoff observa que diversos termos como “'educação', 'pedagogias auto-organizadas', 'pesquisa' e 'produção de conhecimento' começam a atravessar os discursos. O problema é que, no discurso neoliberal, os mesmos termos têm outra intenção: fazer da educação uma ferramenta para a nova 'economia do conhecimento"' (Rogoff, 2008: s/p). Os projetos educativos que se apresentam nos museus e espaços culturais institucionais se restringem na sua maioria a projetos politicamente corretos que satisfazem somente os objetivos institucionais e corporativos dos patrocinadores.

Dada essa situação Bishop questiona como seria possivel reconhecer a diferença entre uma pedagogia estética e as interseções generativas entre arte e educação? Ela lembra que a literatura em arte e pedagogia evita tratar das interseções e das diferenças entre os discursos da arte e da educação. Na sua pesquisa (Bishop 2006, 2012) sobre arte participante e sobre os projetos pedagógicos da última década a autora observa o que acontece quando os artistas trabalham com interfaces pedagógicas: 
- Não são, na maioria das vezes, trabalhos coesos, completos e pensados para uma exposição. A obra, a menos que esteja densamente documentada, não resulta em imagens, e se tem, dificilmente apresenta uma unidade estética.

- São processos longos porque reivindicam relações, procuras, indagações, experiências, experimentos e longas reflexões. Muitas vezes são processos fechados no círculo social dos participantes.

- Os registros são escassos porque são processos longos e é difícil dar uma imagem clara da estrutura e da narrativa a um intercambio invisível e sem forma.

- Estes projetos pedagógicos realizados por artistas não são projetos préfabricados que se aplicam em qualquer lugar, ao contrário, respondem a diversas urgências do momento, surgem da relação que estes artistas estabelecem com seu meio social.

- Nos países do norte europeu e americano, a virada pedagógica na arte é mais uma reação ao constante e crescente fechamento do espaço público e à padronização da educação, enquanto nos países do centro e sul americano se trata mais de compensar aquilo que falta nas instituições sociais, políticas, culturais e educativas.

- A coincidência destes eventos tem um status ontológico duplo: é uma forma de manter a tensão entre estar no mundo e ao mesmo tempo estar fora dele por isso se dirige tanto aos participantes (primeira audiência: estudantes) como a espectadores (segunda audiência: público) ${ }^{24}$.

- Estes eventos enfrentam um duplo dilema: devem manter a tensão entre 0 que é ideal e o que é real na educação e devem manter a tensão entre dirigir 0 artefato artístico a um público universal e a estudantes específicos. A educação é um processo social fechado que não necessita e não pode ser comunicável de maneira efetiva a um público externo (os testes de qualidade são instrumentos apenas quantitativos, inexpressivos e muitas vezes inadequados) e a arte é um processo social aberto que requer de uma comunicabilidade com o mundo. Poucos projetos, observa Bishop,

${ }^{24}$ Pablo Helguera (2011) reconhece para os artistas ainda uma terceira audiência que é a crítica de arte. 
conseguem lidar com essa distância entre os processos da primeira e a segunda audiência.

- A coincidência destes eventos requer de uma grande habilidade para trabalhar com formas, experiências e significados e de muita imaginação e coragem.

Bishop destaca que o domínio da linguagem é muito importante quando se trata de uma 'pedagogia como arte', os projetos pedagógicos mais artísticos se apresentam de uma maneira tal que podem comunicar essa experiência a uma segunda audiência, seja por meio de vídeo, performance, exibição, cátedra ou publicação. Sobretudo, são projetos que, segundo Bishop,

[..] cristalizam um dos problemas centrais de toda prática artística no campo social: nos pedem examinar nossas suposições sobre ambos campos de operação e ponderar as sobreposições produtivas e incompatibilidades que posam surgir de sua conjunção experimental, com as consequências de perpetuar a reinvenção de ambas. (Bishop, 2012: 274)

A forma como o artista se vê a si mesmo como pesquisador, e nesse processo como educador na sua relação com os participantes, é uma das mudanças mais importantes e mais radicais que estão acontecendo na prática da arte e isso traz outras repercussões para a teoria e a historicidade da arte na sua concepção moderna e ocidental. Bishop aponta, por exemplo, uma série de problemas e questionamentos epistemológicos que a virada pedagógica apresenta para os historiadores e críticos de arte: "0 que significa fazer educação como arte? como julgar estas experiências? que tipo de eficácia procuramos? necessitamos participar de primeira mão na experiência para comentar?" (2012: 245).

Por oura parte a virada pedagógica da arte aponta a uma tendência cada vez maior dos artistas de deixar o circuito da arte ou de procurar estratégias que permitam explorar outros campos de forma estética e poética. Vidokle (Madoff, 2009) pensa que já não há mais público que possa completar a função transformadora do objeto de arte crítico, por esse motivo acredita que a exposição não seja mais o lugar adequado para começar essa 
relação transformadora. Assim, sem um público envolvido, ele pensa que a escola possa ser um modelo capaz de devolver o poder de agencia da arte. Bruguera também está mais interessada na educação como arte antes que a arte como educação. Não se trata então de manter o mesmo status com explorações temporárias sobre temas sociais ou científicos, mas atravessar fronteiras identitárias em busca de uma maior corrosão no mundo.

A virada pedagógica enquanto campo de indagação viva ${ }^{25}$ sobre as formas como conhecemos, não somente apresenta novas formas de pesquisa ou investigação, mas sobretudo, novas formas de entender o papel do sujeito artista em trânsito com o sujeito educador que se realiza como sujeito investigador produzindo ideias, formas e situações para o mundo (Sullivan, 2010).

\section{Considerações finais}

O papel do sujeito artista em trânsito como sujeito educador acontece no espaço da investigação. Se na modernidade o sujeito artista devia indagar sobre a sua identidade, na contemporaneidade é mais importante indagar sobre as relações que acontecem nos espaços de hibridação e fluxo. 0 mundo científico ou o campo social adquirem nessa perspectiva uma maior relevância e relação. O papel da arte na construção do conhecimento e na transformação social é cada vez maior e com maior capacidade de se filtrar nas formas da vida.

Mas, seria necessário reconhecer, como Felix Guattari (1995), que a tensão entre arte e vida é fundamental porque se a arte se funde totalmente na vida corre o perigo do seu eclipse. Para evitar esta desaparição ele sugere que a arte deve ter uma dupla finalidade: fazer parte de uma rede social que pode tanto Ihe recusar ou the aceitar e celebrar o Universo da arte como tal porque está sempre em risco de colapso. Os projetos de arte como

\footnotetext{
25 Processo de investigaçao relacionado à vida presente conceitualizado na metodologia $\mathrm{A} / \mathrm{r} /$ tografica ou metodologia de investigação do artista/investigador/professor. É uma forma de Investigação Baseada nas Artes desenvolvida na Universidade de British Columbia no Canadá, que integra teoria, práxis e poética, reflete sobre as identidades em trânsito, indaga sobre a imaginação nos processos de construção de conhecimento e favorece o que os a/r/tógrafos chamam de 'pesquisa viva' ou investigação relacionada à vida presente. (ver DIAS e IRWIN, 2013). 
pedagogia apontam a esta dupla ontologia de tensões entre arte e sociedade, arte e educação, arte e cultura, arte e ciência, arte e política e arte e vida. Isso significa que trabalham nas tensões entre a autonomia e a heteronímia da arte.

Por outra parte, a dupla identidade de artista e educador, que atravessa esses espaços de conflito, produz rompimentos que podem conduzir a mutações no campo da arte e da educação. Na arte essas mudanças começam pelos desafios que apresentam para a prática artística e o sistema da arte, quanto a teóricos, críticos e historiadores. Na educação as mudanças são também importantes porque contaminam os processos de ensino e aprendizagem com aberturas incômodas à imaginação, à singularidade, à diferença, à dissidência, à experiência estética e à criação de territórios de subjetivação.

\section{Referências}

AGUIRRE, Imanol. Cultura Visual, política da estética e educação emancipadora. In: MARTINS, Raimundo; TOURINHO, Irene (Orgs.). Educação da Cultura Visual: conceitos e contextos. Santa Maria: Editora UFSM, 2011.

ARGAN, Giulio Carlo. Arte Moderna: Do lluminismo aos movimentos contemporâneos. São Paulo: Companhia das Letras, 1993.

BAUMAN, Zygmunt. Modernidad Líquida. México: Fondo de Cultura Económica, 2006.

BISHOP, Claire (Org.). Participation. Cambridge: MIT Press, Whitechapel Ventures, 2006. Verso, 2012.

Artificial Hells: participatory art and the politics of spectatorship. London:

BOURRIAUD, Nicolas. Estética relacional. São Paulo: Martins, 2009.

BROSTERMAN, Norman. Inventing Kindergarten. New York: Harry N. Abrams, 1997.

BRUGUERA, Tania. TANIA BRUGUERA. Cátedra Arte de Conducta. Glosario, s/d. Disponível em: <http://www.taniabruguera.com/cms/492-1 Ctedra+Arte+de+Conducta.htm>. Acesso em: 14 jun. 2013.

CAMNITZER, Luis On art, artists, latin america, and other utopias. Texas: University of Texas Press, 2009.

CRIMP, Douglas. On the Museum's Ruins. Cambridge Massachusetts: MIT Press, 1993.

DEWEY, John. Art as Experience. N.Y.: Penguin Group, 2005. 
DIAS, Belidson; IRWIN, Rita (Org.). A/r/tografia. Santa Maria: Editora da UFSM, 2013.

EFLAND, Arthur. A History of Art Education: Intellectual and Social Currents in Teaching the Visual Arts. New York: Teachers College Press, 1990.

FERREIRA, Gloria; COTRIM, Cecília. Clement Greenberg e o debate crítico. Rio de Janeiro: Jorge Zahar Ed., 2001.

FREIRE, Paulo. Pedagogia do Oprimido. Rio de Janeiro: Paz e Terra, 1987. 17 ed.

GUATTARI, Felix. Chaosmosis: an ethico-aesthetic paradigm. Indianapolis: Indiana University Press, 1995.

HELGUERA, Pablo. Education for Socially Engaged Art: a Materials and Tecniques Handbook.New York: Jorge Pinto Books, 2011.

HIGGINS, Hannah. Fluxus Experience. California: University of California Press, 2002.

KRAUSS, Rosalind. Caminhos da Escultura Moderna. São Paulo: Martins Fontes, 1998.

KUONI, Carin (org.). Energy Plan for the Western man: Joseph Beuys in America. N. Y: Four Walls Eight Windows, 1993.

LIPPARD, Lucy. Art Outdoors, In and Out of the Public Domain. Studio International. March- April, 1977.

MADOFF, Steven. Art School: Propositions for the 21st Century. London: The MIT Press, 2009.

NOTES FOR AN ART SCHOOL. Manifesta 6. Nicosia, Cyprus. 2006. Disponível em: <http://manifesta.org/manifesta-6/>. Acesso em: 9 jun. 2013.

PODESVA, L. K. A Pedagogical Turn: Brief Notes on Education as Art. Fillip, 6 Projectile Publishing Society, Vancouver, British Columbia Summer 2007. Disponível em: <http://fillip.ca/content/a-pedagogical-turn>. Acesso em: 12 mar. 20012.

RANCIÈRE, Jacques. Sobre políticas estéticas. Barcelona: Museo de Arte Contemporáneo, Universidad Autónoma de Barcelona, 2005.

Aesthetics and its discontents. UK: Polity Press, 2009a.

A Partilha do Sensivel. São Paulo: Editora 34, 2009b. $2^{\text {a Ed. }}$

ROGOFF, Irit. Turning. e-flux journal. \#0, November 2008. Disponível em: <http://www.e-flux.com/journal/turning/>. Acesso em 11 abr. 2012.

SUASSUNA, Ariano. Iniciação à Estética. $9^{\circ}$ Ed. Rio de janeiro: José Olympio, 2008.

SULLIVAN, Graeme. Art Practice as Research: Inquiry in Visual Arts. LA: SAGE Publications, 2010.

VERWOERT, Jan. The Boss: On the Unresolved Question of Authority in Joseph Beuys Ouvre and Public Image. e-flux journal. December 2008. Disponivel em: <http://www.e-flux.com/journal/turning/>, Acesso em: 11 abr. 2012.

Artigo recebido em janeiro de 2016. Aprovado em abril de 2016 